\title{
DETERMINATION OF THE CRITICAL DISTANCE IN THE PROCEDURE OF EXPLOSIVE WELDING
}

\author{
Miloš S. Lazarevića ${ }^{a}$ Bogdan P. Nedićb, \\ Jovica Đ. Bogdanov ${ }^{\mathrm{c}}$, Stefan V. Đurićd \\ ${ }^{a}$ University of Kragujevac, Faculty of Engineering, \\ Kragujevac, Republic of Serbia, \\ e-mail: laky_boy_kg@hotmail.com, \\ ORCID iD: (i)https://orcid.org/0000-0002-5441-4482 \\ ${ }^{\mathrm{b}}$ University of Kragujevac, Faculty of Engineering, \\ Kragujevac, Republic of Serbia, \\ e-mail: nedic@kg.ac.rs, corresponding author, \\ ORCID iD: (1) https://orcid.org/0000-0002-4236-3833 \\ ${ }^{\mathrm{C}}$ University of Defence in Belgrade, Military Academy, Department for \\ Military Chemical Engineering, Belgrade, Republic of Serbia, \\ e-mail: bjbogdanov@yahoo.com, \\ ORCID iD: (iohttp://orcid.org/0000-0001-7995-3004 \\ d University of Kragujevac, Faculty of Engineering, \\ Kragujevac, Republic of Serbia, \\ e-mail: stefandjuric992@gmail.com, \\ ORCID iD: (Ohttps://orcid.org/0000-0003-0660-7551
}

DOI: 10.5937/vojtehg68-26683; https://doi.org/10.5937/vojtehg68-26683

FIELD: Mechanical engineering

ARTICLE TYPE: Original scientific paper

\begin{abstract}
:
Introduction/purpose: When performing the explosive welding procedure, for the safety of workers, it is necessary to take into account the minimum distance between the workers and the place of explosion at the time of explosion. Negligence can cause temporary hearing loss, rupture of the eardrum and in some cases even the death of workers. The aim of this paper is to determine the critical distance based on the mass of explosive charge required for explosive welding, provided that the limit pressure is $6.9 \mathrm{kPa}$ in the case of temporary hearing loss and $35 \mathrm{kPa}$ in the case of eardrum rupture. This paper does not take into account other effects of the explosion than those caused by the shock wave.
\end{abstract}

ACKNOWLEDGMENT: This paper presents the results of the research in Project TR35034: Research on the application of modern unconventional technologies in manufacturing companies with the aim of increasing efficiency, product quality, reducing costs and saving energy and materials, which is financially supported by the Ministry of Education, Science and Technological Development of the Republic of Serbia. 
Methods: Depending on the type of explosion, the equivalent explosive mass was calculated. Based on the equivalent explosive mass and the limit pressure, the minimum distances were calculated using the Sadovsky and Kingery-Bulmash equations.

Results: The corresponding tables show the results of the calculation of the critical distance of workers from the place of the explosion when there may be temporary hearing loss or rupture of the eardrum. The calculated value of the critical explosion distance by the KingeryBulmash method, under the condition of the maximum pressure for temporary hearing loss, is $5.62 \%$ lower than the distance value obtained by the Sadovsky method while the value of the critical explosion distance calculated by the Kingery-Bulmash method, under the condition of the maximum pressure for eardrum rupture, is $7.83 \%$ lower than the value obtained by the Sadovsky method.

Conclusion: The results of the calculation showed that the critical distance from the explosion can be successfully calculated and that the obtained values have small differences depending on the applied calculation method.

Key words: explosion welding, critical distance, shock wave, eardrum damage, risk matrix.

\section{Introduction}

Explosive welding is a process in which the chemical energy of explosives is used to create a welded joint. Part of the internal energy of explosives is converted into kinetic energy of gaseous detonation products which cause metal particles to move and form a welded joint. This technological process is used to join two dissimilar materials that cannot otherwise be joined by classical welding processes or their joining is considerably more difficult (e.g. production of clad materials).

The advantage of this procedure is that cheap materials, e.g. aluminum and steel, can be used to form inexpensive materials with excellent mechanical and chemical characteristics. Also, with this procedure, it is possible to obtain multilayer materials of large areas. For this reason, this technology is increasingly used in shipbuilding for the manufacture of ship hulls, in chemical industry for manufacturing tanks and boilers, and for the manufacture of electrical contacts. Explosive welding is a process accompanied by certain hazards. With this in mind, all safety aspects of the application of this procedure must be taken into account. 
When performing the explosive welding procedure, for the safety of workers, it is necessary to take into account the minimum distance between workers and the place of explosion at the time of explosion. Negligence can cause temporary hearing loss and rupture of the eardrum. Severe consequences and death are caused by damage to the lungs and other internal organs.

The aim of this work is to determine the critical distance based on the explosive charge mass and required for explosive welding under the condition of the maximum limit pressure for temporary hearing loss and the maximum limit pressure for eardrum rupture.

\section{Explosive welding}

Explosion of metals is achieved due to a very fast collision of metals under the action of detonation products, with the appearance of high pressure and plastic deformations in the waveform at the joint boundary and adiabatic local heating of metal surface layers (Pejčinović, 2000), (Ghomi, 2009), (Bataev et al, 2019).

The joining process consists of placing welded plates in parallel or at a certain angle at an appropriate distance from each other. An explosive charge of a certain thickness is placed on the plate to be pushed. Initiation is usually performed at a point on one of the sides of the explosive charge. After initiating the detonation process in an explosive charge, a very high pressure is created in the detonation products.

The detonation products suppress the upper plate (Figure 1), which collides with the lower plate at high speed. The collision is performed gradually, during which the pushed plate rotates and turns into a quasiliquid state.

At the same time, a tangential component of the collision velocity appears in the direction of propagation of the detonation wave which makes the metal joint zone wavy during plastic deformation (Pejčinović, 2000), (Blazynski, 1983). 


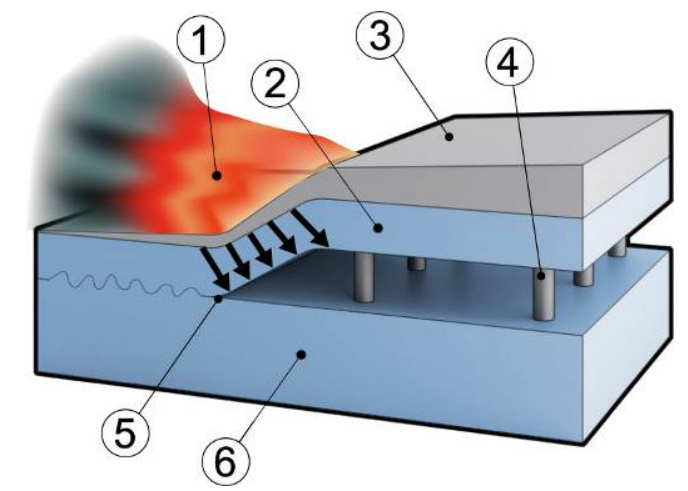

Figure 1 - Explosive welding scheme: 1 - Detonation products, 2 - coating for base material, 3 - explosive, 4 - spacers, 5 - connection point, 6 - base material (Manufacturing Guide, 2020)

Puс. 1 - Схема сварки взрывом: 1 - продукты детонации, 2 - покрытие для основного материала, 3 - взрывчатка, 4 - проставки, 5 - точка соединения, 6основной материал (Manufacturing Guide, 2020)

Слика 1 - Шематски приказ експлозивног заваривања: 1 - продукти детонације, 2 - облога за основни материјал, 3 - експлозив, 4 - дистанцери, 5 - тачка спајања, 6 - основни материјал (Manufacturing Guide, 2020)

\section{Hearing damage criteria}

Hearing damage occurs due to the action of shock waves (UT) in the air as a consequence of the action of explosion. An explosion produces a primary wave (compression wave) and a secondary wave (dilution wave). Damage to the hearing organs under the action of the shock wave depends on the distance of the person from the center of the explosion, on the position of the hearing organs in relation to the shock wave, as well as on the previous condition of the damaged ear (presence of inflammatory processes, etc.) (Shangyuan, 2018), (Gan et al, 2016).

It has been found that temporary hearing loss can occur at a pressure level below $6.9 \mathrm{kPa}$ (Beveridge, 2011), while the eardrum rupture threshold is at a pressure of $35 \mathrm{kPa}$ that occurs during an explosion (Stewart, 2006).

Injuries caused by the explosion shock wave are proportional to the amount of explosive and inversely proportional to the distance from the place of explosion (Solomos et al, 2020). In the case of an explosion of 8 $\mathrm{kg}$ of TNT, at distances of $1-3.5 \mathrm{~m}$, mortality is over $99 \%$ while at a distance of about $5 \mathrm{~m}$, mortality is over $50 \%$. At distances of $6-8.5$ meters, mortality is over $20 \%$, while at a distance of over 10 meters, mortality is lower than 5\%. (Waldau et al, 2015) 
It should be emphasized that the adopted critical values are conditional. In the works (BlackBox Biometrics, 2018), (Stamatović, 1995), data on shock wave overpressure values for different degrees of injuries can be found.

\section{Explosive characteristics}

Within this paper, a possible impact of Amonex 1 explosives was analyzed (Table 1). It is a powder explosive made on the basis of ammonium nitrate (AN) and TNT (TNT). The percentage of the chemical composition of Amonex 1 is $82 \%$ ammonium nitrate, $16 \%$ TNT, $0.6 \%$ carboxymethyl cellulose, $0.4 \%$ calcium stearate and $1 \%$ base paraffin oil (Trayal Corporation, 2008). It has low sensitivity to impact and friction, which makes this explosive safe to handle and transport. It is used, first of all, for mass mining blasting in underground and surface exploitation, and for blasting from soft to very hard rock masses where methane and explosive coal dust are not present (Trayal corporation, 2020). It is not water resistant, which is why it is used for blasting in dry and wet mine wells, so it is not suitable for blasting in wells with water.

Table 1 - Characteristics of AMONEX 1-4 powder explosives (Trayal corporation, 2020)

Таблица 1 - Характеристики порошковых взрывчатых веществ AMONEX 1-4

(Trayal corporation, 2020)

Табела 1 - Карактеристике прашкастих експлозива AMONEX 1-4 (Trayal corporation, 2020)

\begin{tabular}{|c|c|c|c|c|c|}
\hline \multirow{2}{*}{ PROPERTY } & \multirow{2}{*}{ Unit } & \multicolumn{4}{|c|}{ Type of explosive } \\
\cline { 3 - 6 } & & $\begin{array}{c}\text { AMONEX } \\
1\end{array}$ & $\begin{array}{c}\text { AMONEX } \\
2\end{array}$ & $\begin{array}{c}\text { AMONEX } \\
3\end{array}$ & $\begin{array}{c}\text { AMONEX } \\
4\end{array}$ \\
\hline Density & $\mathrm{g} / \mathrm{cm}^{3}$ & $1.02-1.10$ & $1.02-1.10$ & $0.96-1.04$ & $0.96-1.04$ \\
\hline Velocity of detonation, $\mathrm{min}$ & $\mathrm{m} / \mathrm{s}$ & 4100 & 3900 & 3600 & 3200 \\
\hline Gas volume & $\mathrm{dm}^{3} / \mathrm{kg}$ & 975 & 984 & 993 & 1004 \\
\hline Oxigen balance & $\%$ & +0.13 & +0.08 & +0.10 & +0.17 \\
\hline Heat of explosion & $\mathrm{kJ} / \mathrm{kg}$ & 4103 & 4082 & 4040 & 3892 \\
\hline Temperature of explosion & $\mathrm{K}$ & 2740 & 2725 & 2707 & 2661 \\
\hline Presure of detonation & $\mathrm{kbar}$ & 45 & 40 & 33 & 27 \\
\hline Initiation & & \multicolumn{5}{|c|}{ blasting cap $\mathrm{N}^{\circ} 8$} \\
\hline
\end{tabular}

\section{Determination of theTNT equivalent}

Most of the equations for calculating the shock wave and pulse are based on the TNT equivalent. Therefore, it is desirable to know their equivalent mass for different explosives. 


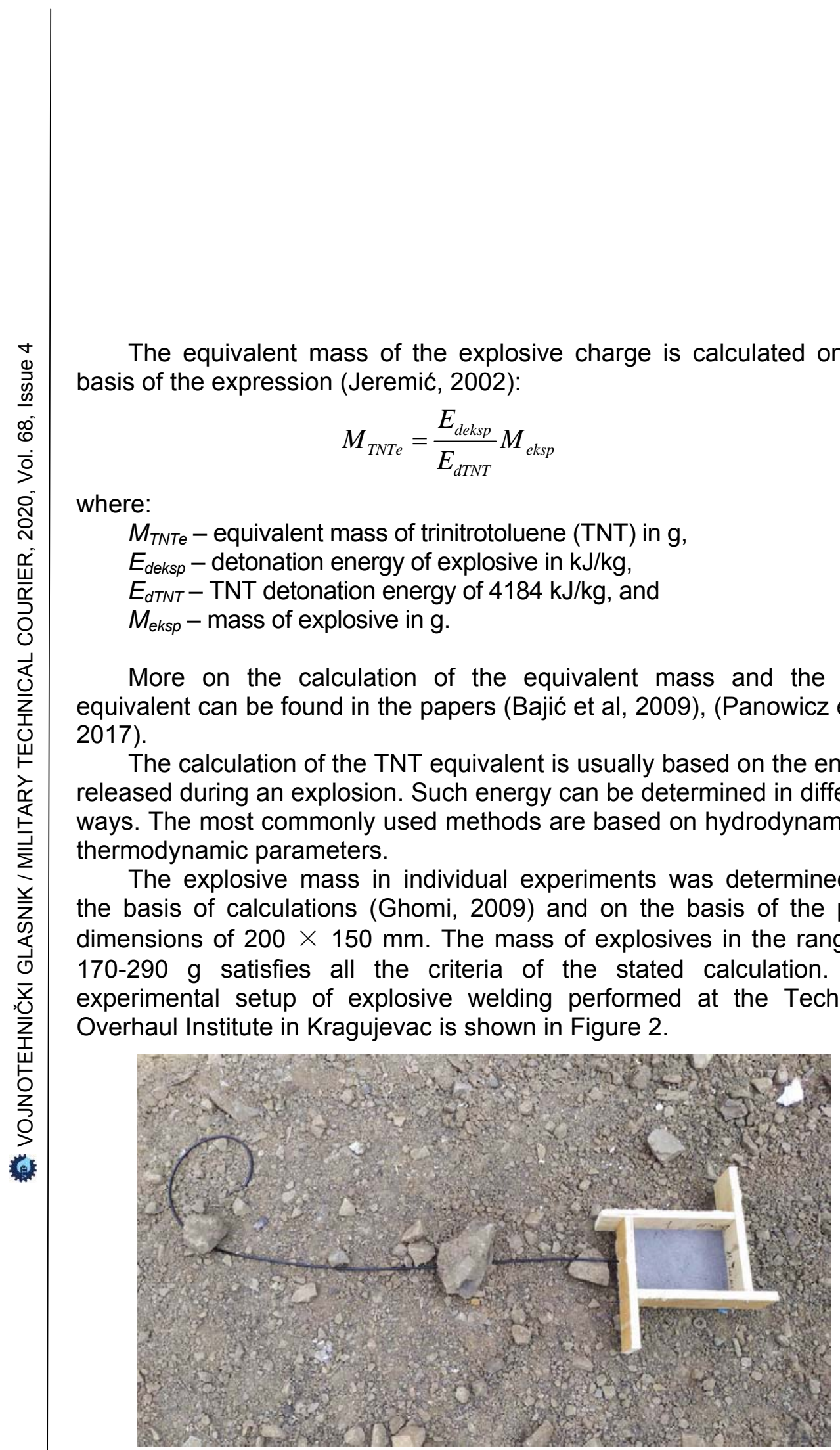

$$
\begin{aligned}
& M_{T N T e} \text { - equivalent mass of trinitrotoluene }(T N T) \text { in g, } \\
& E_{\text {deksp }} \text { - detonation energy of explosive in } \mathrm{kJ} / \mathrm{kg}, \\
& E_{d T N T}-\text { TNT detonation energy of } 4184 \mathrm{~kJ} / \mathrm{kg} \text {, and } \\
& M_{\text {eksp }} \text { - mass of explosive in g. }
\end{aligned}
$$

More on the calculation of the equivalent mass and the TNT equivalent can be found in the papers (Bajić et al, 2009), (Panowicz et al,

The calculation of the TNT equivalent is usually based on the energy released during an explosion. Such energy can be determined in different ways. The most commonly used methods are based on hydrodynamic or thermodynamic parameters.

The explosive mass in individual experiments was determined on the basis of calculations (Ghomi, 2009) and on the basis of the plate dimensions of $200 \times 150 \mathrm{~mm}$. The mass of explosives in the range of $170-290 \mathrm{~g}$ satisfies all the criteria of the stated calculation. The experimental setup of explosive welding performed at the Technical Overhaul Institute in Kragujevac is shown in Figure 2.

Figure 2 - Experimental setting for explosive welding Puc. 2 - Экспериментальная установка сварки взрывом Слика 2 - Експериментална поставка експлозивног заваривања 
The calculated values of the equivalent masses of AMONEX 1 explosives depending on the mass of the explosive charge for the required critical distance calculations within this paper are shown in Table 2.

Table 2 - Explosive charge mass and the equivalent mass of AMONEX 1

Таблица 2 - Масса заряда взрывчатого вещества и эквивалентная масса AMONEX 1

Табела 2 - Маса експлозивног пуњења и еквивалентна маса AMONEX 1

\begin{tabular}{|c|c|c|c|c|c|c|}
\hline Type of explosive & Unit & \multicolumn{5}{|c|}{ AMONEX 1 } \\
\hline Experiment number $\mathrm{N}$ & & 1 & 2 & 3 & 4 & 5 \\
\hline $\begin{array}{c}\text { Explosive charge mass } \\
\mathrm{M}_{\text {eksp }}\end{array}$ & $\mathrm{g}$ & 170 & 190 & 220 & 250 & 290 \\
\hline TNT equivalent $\mathrm{E}_{\text {deksp }} / \mathrm{E}_{\mathrm{dTNT}}$ & & \multicolumn{5}{|c|}{0.981} \\
\hline $\begin{array}{c}\text { Equivalent mass of } \\
\text { explosives } \mathrm{M}_{\mathrm{TNT}}\end{array}$ & $\mathrm{g}$ & 167 & 186 & 216 & 245 & 285 \\
\hline $\begin{array}{c}\text { Double equivalent mass of } \\
\text { explosives } \mathrm{m}_{\mathrm{p}}\end{array}$ & $\mathrm{g}$ & 333 & 370 & 432 & 491 & 569 \\
\hline
\end{tabular}

\section{Determination of the critical distance of an explosion}

The main characteristics of the shock wave are the overpressure at the front of the shock wave and the duration of the compression wave, the values of which depend on the type of explosive, the mass of the explosive and the distance from the place of the explosion.

In addition to Sadovsky's formula (Sadovsky, 1952), there are numerous newer relations for determining the overpressure at the shock wave front, such as the Brode formula (Brode, 1955), the Kinney-Graham formula (Kinney \& Graham, 1985), the Kingery-Bulmash formula, (Kingery \& Bulmash, 1984), etc. For the sake of simplicity, this paper will be based on Sadovsky's formula with two groups of the $k_{1}, k_{2}$, and $k_{3}$ coefficients (Table 3) and the Kingery-Bulmash method.

Based on the experimental results for spherical shock waves formed by a detonation of a certain mass of TNT, Sadovsky (Sadovsky, 1952) proposed an empirical equation for the calculation of overpressure at the shock wave front in the form:

$$
\Delta \mathrm{p}=k_{1} \frac{m_{e}^{\frac{1}{3}}}{r}+k_{2} \frac{m_{e}^{\frac{2}{3}}}{r^{2}}+k_{3} \frac{m_{e}}{r^{3}}
$$

By arranging the equation we get: 


$$
\Delta \mathrm{p} \cdot r^{3}-k_{1} m_{e}^{\frac{1}{3}} r^{2}-k_{2} m_{e}^{\frac{2}{3}} r-k_{3} m_{e}=0
$$

where:

$\Delta p$ - overpressure at the shock wave front in bar $\left(1 \mathrm{bar}=10^{5} \mathrm{~Pa}\right)$,

$m_{e}$ - mass of explosive charge in $\mathrm{kg}$,

$r$ - distance from the center of the explosion in $\mathrm{m}$, and

$k_{1}, k_{2}, k_{3}$-empirical coefficients depending on the type of explosive charge.

For TNT in the case of an above-ground explosion (at an infinite distance from the ground), the empirical coefficients can be adopted according to Table 3 . In the following work, the results with different groups of $k_{1}, k_{2}$, and $k_{3}$ coefficients from Table 3 will be presented.

In the case of a surface explosion, the shock wave in the air propagates in the shape of a hemisphere (twice the volume), so the overpressure is higher in that case. Therefore, in equation (2), twice the mass value is taken as the mass of the explosive charge (Andreev et al, 2004).

Table 3 - Coefficients $k_{1}, k_{2}$, and $k_{3}$ in TNT above-ground explosions (Andreev et al, 2004), (Bajić et al, 2009).

Таблица 3 - Коэфффициенты k, k, k, в зависимости от типа взрыва (Andreev et al, 2004), (Bajić et al, 2009).

Табела 3 - Коефрицијенти $k_{1}, k_{2}, k_{3}$ у зависности од надземне експлозије TNT (Andreev et al, 2004), (Bajić et al, 2009).

\begin{tabular}{|c|c|c|}
\hline Coefficient & $\begin{array}{c}\text { Above-ground explosion } \\
\text { (Andreev et al, 2004) }\end{array}$ & $\begin{array}{c}\text { Above-ground explosion } \\
\text { (Bajić et al, 2009) }\end{array}$ \\
\hline$k_{1}$ & 0.84 & 1.02 \\
\hline$k_{2}$ & 2.7 & 4.36 \\
\hline$k_{3}$ & 7 & 14 \\
\hline
\end{tabular}

As the surface explosion causes soil deformation, it is necessary to introduce a coefficient $\eta$ that depends on the type of soil (Table 4), so that the equivalent (calculated) mass of explosives can be calculated using expression (3):

$$
m_{p}=2 \cdot \eta \cdot M_{T N T e}
$$


Table 4 - Values of the coefficient $\eta$ depending on the soil type (Andreev et al, 2004) Таблица 4 - Значения коэффрициента $\eta$ в зависимости от типа почвы (Andreev et al, 2004)

Tabela 4 - Вредности коефицијента $\eta$ у зависности од типа тла (Andreev et al, 2004)

\begin{tabular}{|c|c|c|c|c|c|c|}
\hline $\begin{array}{c}\text { Obstacle } \\
\text { type }\end{array}$ & $\begin{array}{c}\text { Steel } \\
\text { plate }\end{array}$ & $\begin{array}{c}\text { Reinforced } \\
\text { concrete } \\
\text { plate }\end{array}$ & $\begin{array}{c}\text { Concrete, } \\
\text { rock }\end{array}$ & $\begin{array}{c}\text { Hard } \\
\text { ground }\end{array}$ & $\begin{array}{c}\text { Medium } \\
\text { hard } \\
\text { ground }\end{array}$ & Water \\
\hline$\eta$ & 1 & $0.95-1$ & $0.85-0.9$ & $0.7-0.8$ & $0.6-0.65$ & $0.55-0.6$ \\
\hline
\end{tabular}

In this paper, the coefficients $k_{1}, k_{2}$, and $k_{3}$ are presented in Table 3 according to the work (Andreev et al, 2004) and according to the work (Bajić et al, 2009). Both cases assume that, in the calculation of explosive welding, twice the mass of explosive charge $\mathrm{mp}$ is adopted according to equation (3) and the coefficient $\eta$ for the steel plate. Other values of the coefficient $\eta$ will not be considered.

The solution of equation (2) is obtained by reducing it to the following form:

$$
y^{3}+p \cdot y+q=0
$$

where $p$ and $q$ have the following values:

$$
\begin{gathered}
p=-\frac{m_{p}{ }^{\frac{2}{3}}\left(k_{1}{ }^{2}+3 k_{2} \Delta \mathrm{p}_{\varphi}\right)}{3 \Delta \mathrm{p}_{\varphi}{ }^{2}} \\
q=-\frac{m_{p}\left(27 k_{3} m_{p} \Delta \mathrm{p}_{\varphi}{ }^{2}+9 k_{1} k_{2} \Delta \mathrm{p}_{\varphi}+2 k_{1}{ }^{3}\right)}{27 \Delta \mathrm{p}_{\varphi}{ }^{3}}
\end{gathered}
$$

The calculation of the discriminant $D$ is performed according to the following equation:

$$
D=\frac{q^{2}}{4}+\frac{p^{3}}{27}
$$

Using the Cardano equation, the solutions are obtained by $y$ :

$$
y=\sqrt[3]{-\frac{q}{2}+\sqrt{D}}+\sqrt[3]{-\frac{q}{2}-\sqrt{D}}
$$

To obtain the solution of the cubic equation, the following equation is used: 


$$
r=y-\frac{k_{1} m_{p^{\frac{1}{3}}}}{3 \Delta \mathrm{p}_{\varphi}}
$$

The dependence of a critical distance as a function of pressure (Sadovsky method) is shown in Figure 3.

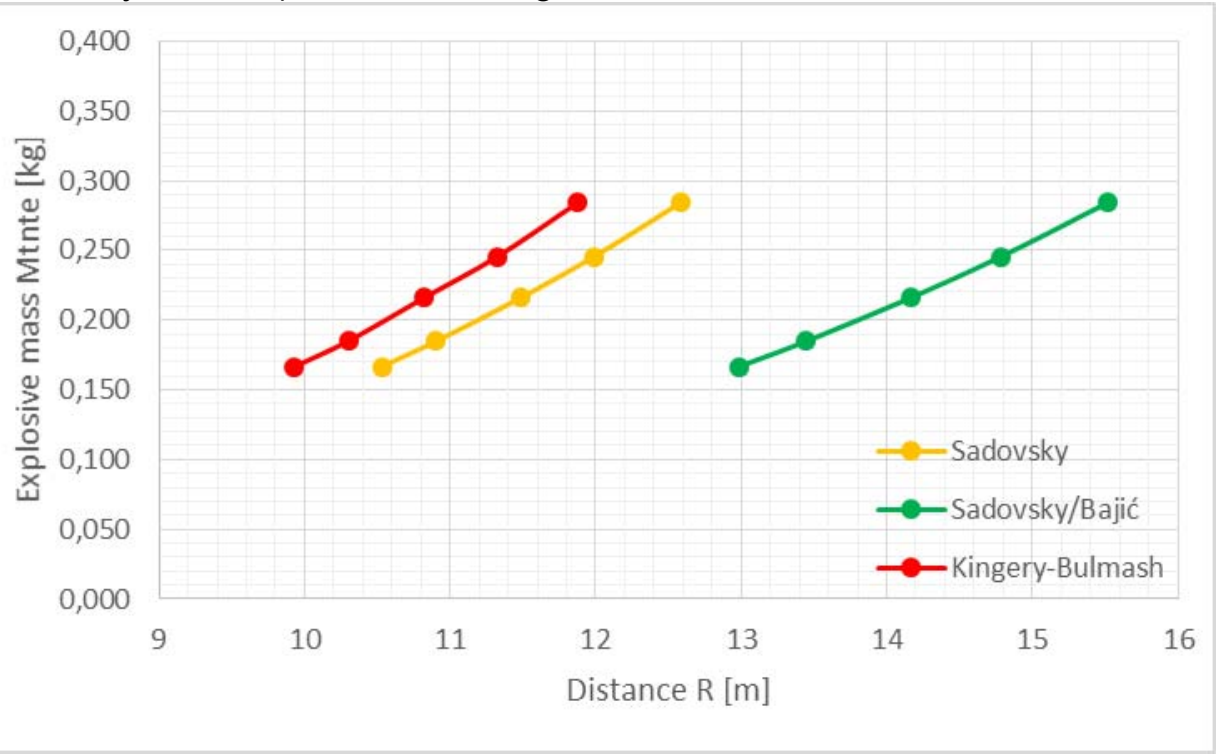

Figure 3-Critical distance as a function of pressure

Pис. 3 - Критическое расстояние в зависимости от давления

Слика 3 - Критично растојање у зависности од притиска

In Figure 3 , the solid lines denote the coefficients $k_{1}, k_{2}$, and $k_{3}$ according to the work (Andreev et al, 2004), while the dashed lines refer to the coefficients according to the work (Bajić et al, 2009) in Table 4.

In addition to the Sadovsky method, the Kingery-Bulmash method is also used in this paper. The Kingery-Bulmash method is used in international regulations (United Nations, 2015) and is more applicable in this case.

In the case of a surface explosion, the Kingery-Bulmash shock wave pressure polynomial is:

$$
\begin{gathered}
Y=C_{0}+C_{1} U+C_{2} U^{2}+C_{3} U^{3}+\ldots \ldots . .+C_{n} U^{n} \\
U=K_{0}+K_{1} T \\
T=\log _{10}\left(R \sqrt[3]{M_{\text {TNTe }}}\right)
\end{gathered}
$$

where:

$T$ - Logarithm of distance with base ten, $\mathrm{m}$, 
$K_{0}, K_{1}-$ coefficients,

$C_{1}-C_{9}$ - coefficients, and

$R$ - distance, $\mathrm{m}$.

These equations have an applicability range of 0.05 to $40 \mathrm{~m}$.

The parameters of the Kingery-Bulmash pressure polynomial at the front of the shock wave are shown in Table 5.

Table 5 - Parameters of the Kingery-Bulmash polynomial for the pressure at the front of the shock wave (United Nations, 2015)

Таблица 5 - Параметры многочлена Кингери и Булмаша для давления во фронте ударной волны (United Nations, 2015)

Табела 5 - Параметри полинома Kingery-Bulmash-a за притисак на челу ударног таласа (United Nations, 2015)

\begin{tabular}{|c|c|}
\hline Parameters & Numeric value \\
\hline$K_{0}$ & -0.214362789151 \\
\hline$K_{1}$ & 1.35034249993 \\
\hline$C_{1}$ & 2.78076916577 \\
\hline$C_{2}$ & -1.6958988741 \\
\hline$C_{3}$ & -0.154159376846 \\
\hline$C_{4}$ & 0.514060730593 \\
\hline$C_{5}$ & 0.0988534365274 \\
\hline$C_{6}$ & -0.293912623038 \\
\hline$C_{7}$ & -0.0268112345019 \\
\hline$C_{8}$ & 0.109097496421 \\
\hline$C_{9}$ & 0.00162846756311 \\
\hline$C_{10}$ & -0.0214631030242 \\
\hline$C_{11}$ & 0.0001456723382 \\
\hline$C_{12}$ & 0.00167847752266 \\
\hline
\end{tabular}

The numerical values for the constants " $C$ " and " $K$ " are the values for $1 \mathrm{~kg}$ of TNT equivalent.

For other explosives, it is required to first estimate the TNT equivalent.

Many states use rules regulating explosives, their quantity and distance from explosives where people are at risk. These rules are known as the quantity-distance criteria (Q-D), (NATO, 2010) and are based on the approach derived from the Hopkinson-Cranz scaling law which is further supplemented by a series of coefficients (equations 7 and 8). (United Nations, 2015) 
This is the basis of much of the work on estimating the appropriate quantities and separation distances.

The dependence of a critical distance as a function of pressure (Kingery-Bulmash method) is shown in Figure 4.

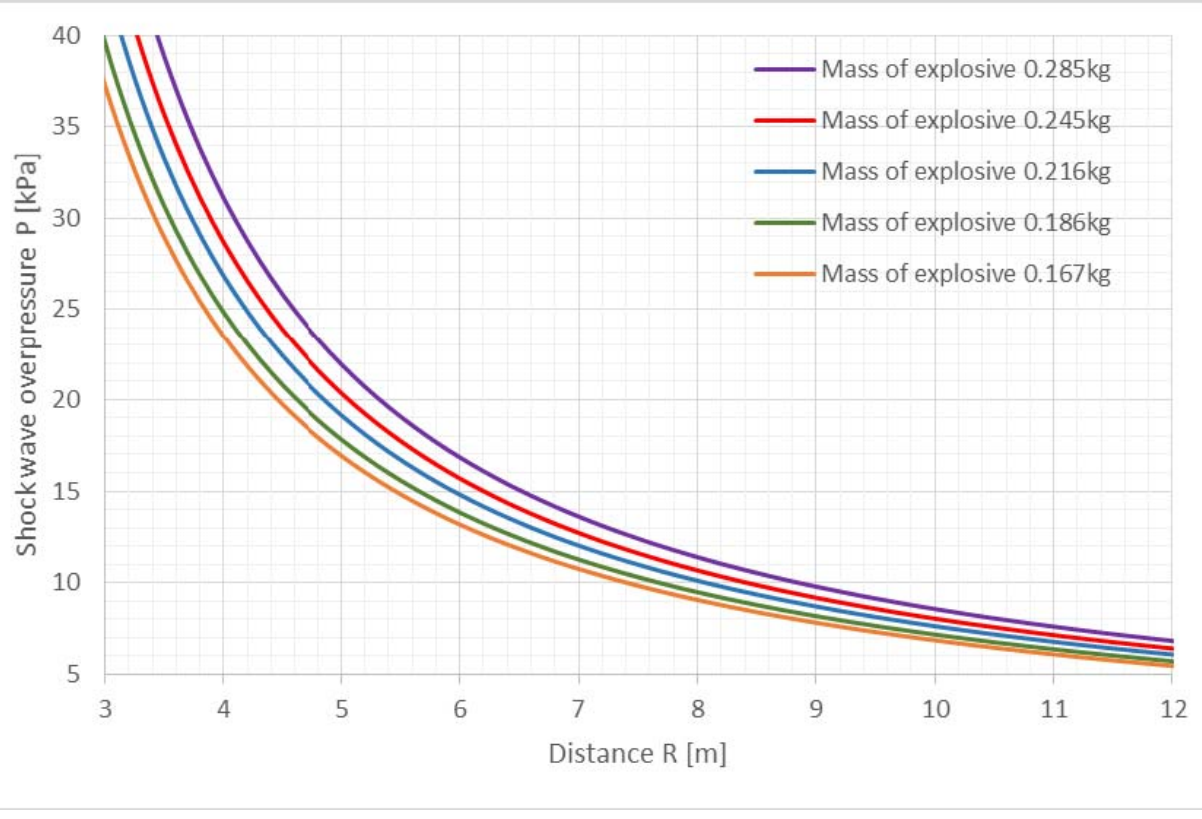

Figure 4-Critical distance as a function of pressure in the case of temporary hearing loss

Puс. 4 - Критическое расстояние в зависимости от давления в случае временной потери слуха

Слика 4 - Критично растојање у зависности од притиска у случају привременог губитка слуха

\section{Critical distance as a function of explosive charge mass}

The paper gives a calculation for Amonex 1 explosive, because it is the strongest commercial explosive from that group (Table 2). Therefore, the critical distance will have the greatest value.

Critical distance determination was performed for two boundary cases:

- critical distance in a case of temporary hearing loss,

- critical distance in a case of rupture of the eardrum. 
Both cases assume that an explosion during explosive welding occurs on a metal plate (coefficient $\eta=1$, Table 4). By including the coefficients $k_{1}, k_{2}$, and $k_{3}$ (Table 3 ), the equivalent masses of explosives obtained by equation (1) and the limit pressure in the case of temporary hearing loss of $6.9 \mathrm{kPa}$ and $35 \mathrm{kPa}$ in the case of eardrum rupture in equation (2), critical distance in a surface explosion is determined.

The methodology for determining the critical distance as a function of explosive charge mass by the Kingery-Bulmash method will be performed according to a similar principle.

By substituting the critical diameter $R$ and the equivalent mass of MTNTe explosives into equation (7), the parameter $T$ is obtained. By replacing the coefficients (Table 5 ) $K_{0}, K_{1}$, and equation (7) with equation (6), the parameter $U$ is obtained. By subsituting equation (6) in equation (5), the pressure at the front of the shock wave is obtained depending on the distance.

Figure 5 shows the dependences of the critical distance as a function of the mass of the explosive, under the assumption of the limit pressure that causes temporary hearing loss.

In Figure 5, the yellow line represents the results of the calculation according to the work (Andreev et al, 2004), the green line refers to the work (Bajić et al, 2009) and the red line denotes the Kingery-Bulmash method.

Figure 6 shows the dependences of the critical distance as a function of the mass of the explosive, assuming the limit pressure that causes the eardrum to burst.

In Figure 6, the yellow line represents the results of the calculation according to the work (Andreev et al, 2004), while the green line represents those based on the work (Bajić et al, 2009). The red line refers to the Kingery-Bulmash method. 


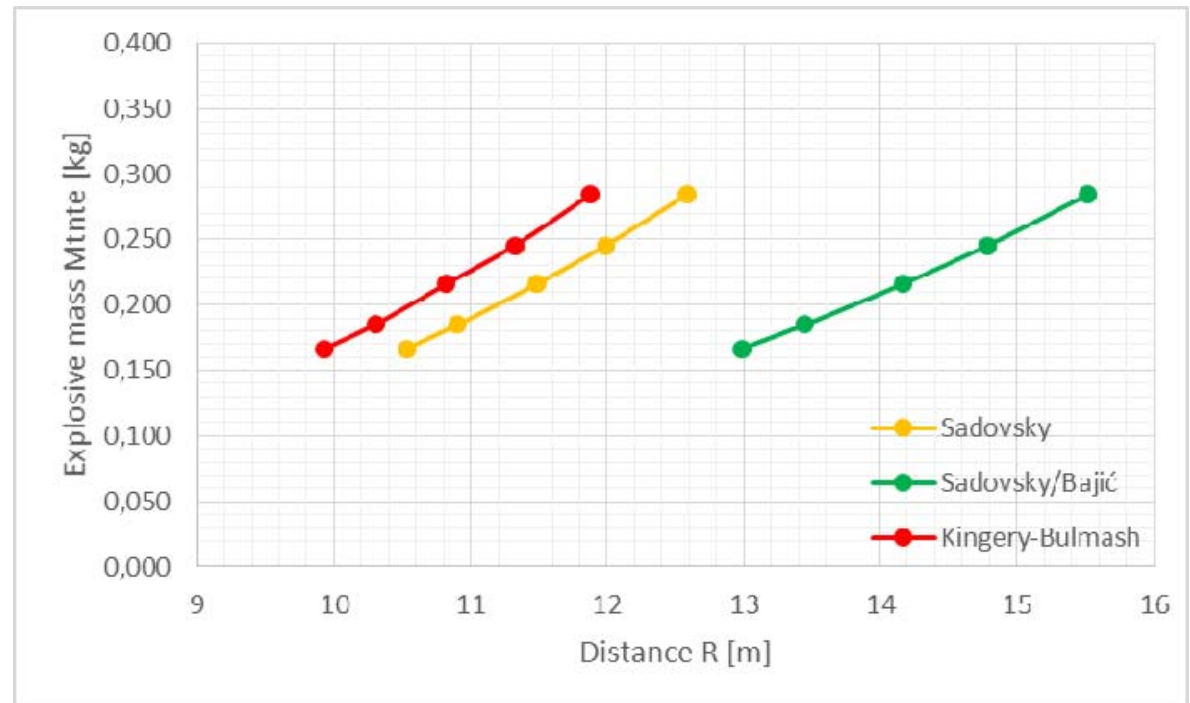

Figure 5 - Critical distance as a function of mass in the case of temporary hearing loss Puc. 5 - Критическое расстояние в зависимости от массы в случае временной потери слуха

Слика 5 - Критично растојање у функцији масе у случају привременог губитка слуха

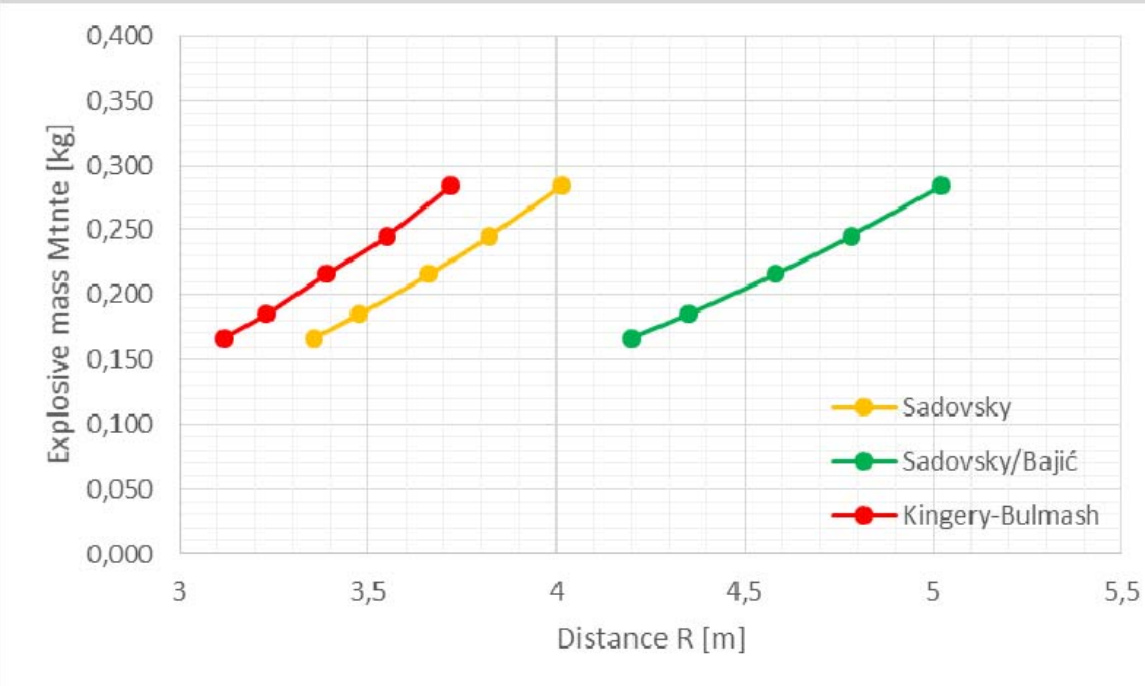

Figure 6-Critical distance as a function of mass in the case of eardrum rupture Puс. 6 - Критическое расстояние в зависимости от массы при разрыве барабанной перепонки

Слика 6 - Критично растојање у фрункциј масе у случају пуцања бубне опне 


\section{Risk matrix}

Considering the stated results from the previous chapters, a risk matrix was formed. The risk matrix is shown in Figure 7. The maximum values of the critical distance were adopted to form the risk matrix. The critical distance obtained by the Sadovsky method in the case of the maximum equivalent mass of Amonex 1 explosives for the case of temporary hearing loss is $12.59 \mathrm{~m}$ and 15.52 , while the critical distance in the case of the maximum equivalent mass of the Amonex 1 explosive for the case of eardrum rupture is $4.01 \mathrm{~m}$ and $5.02 \mathrm{~m}$, respectively.

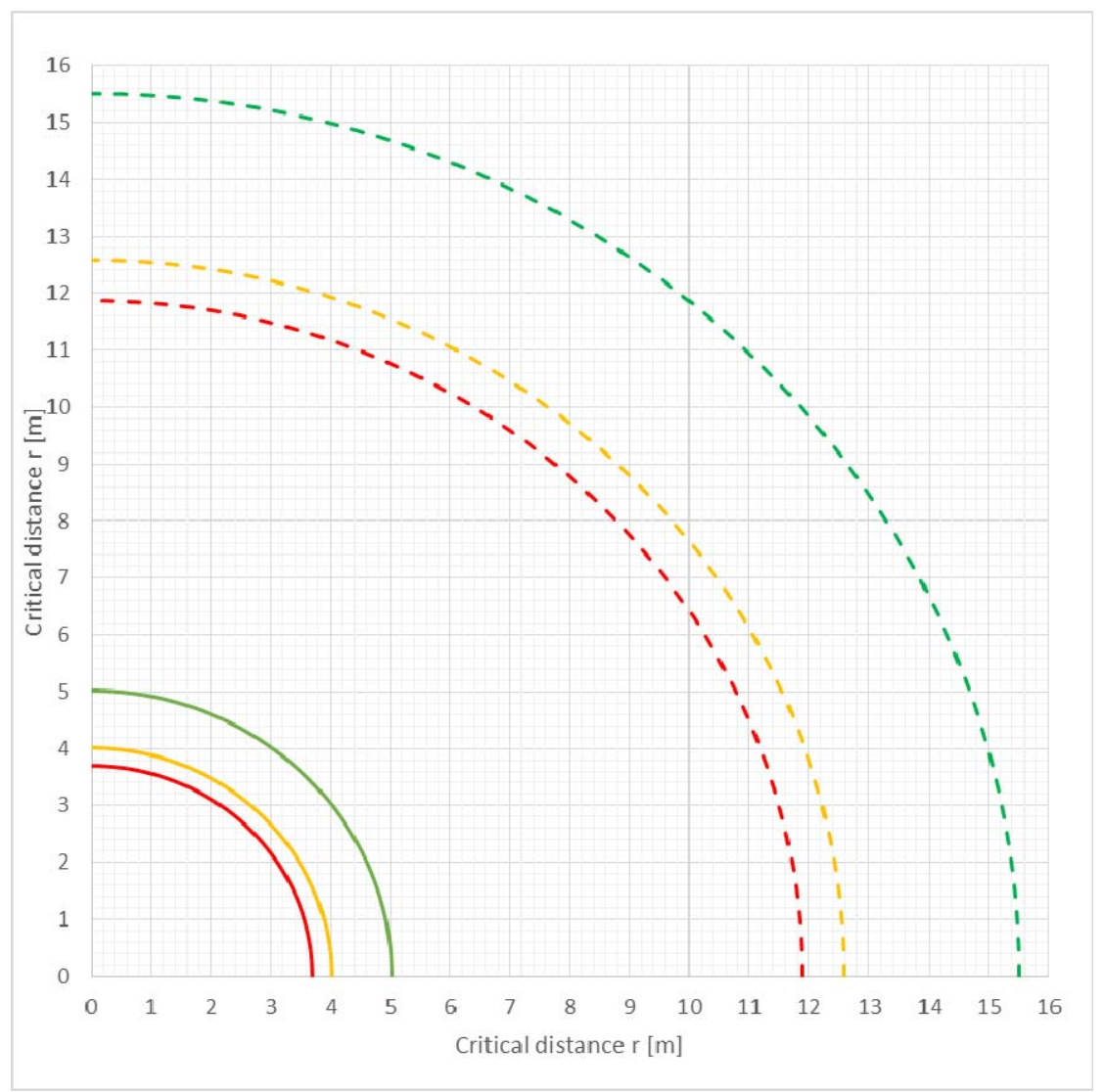

Figure 7 - Risk matrix of the critical distance

Puc. 7 - Матрица рисков критического расстояния

Слика 7 - Матрица ризика критичног растојања 
The critical distance obtained by the Kingery-Bulmash method, in the case of the maximum equivalent mass of Amonex 1 explosives in the case of temporary hearing loss is $11.88 \mathrm{~m}$, while the critical distance in the case of the maximum equivalent mass of Amonex 1 explosives in the case of eardrum rupture is $3.72 \mathrm{~m}$.

In Figure 7, the red lines represent the critical distances obtained by the Kingery-Bulmash method. The green and orange lines represent the critical distances obtained by the Sadovsky method with the coefficients $\mathrm{k}_{1}, \mathrm{k}_{2}$, and $\mathrm{k}_{3}$ according to the work (Andreev et al, 2004) and according to the work (Bajić et al, 2009), respectively. The solid lines represent the critical distances that would cause the eardrum to rupture, while the dashed lines represent the critical distances that would cause temporary hearing loss. More serious injuries can occur in the zone within the solid lines.

Table 7 shows the critical distances under the condition of the maximum pressure for temporary hearing loss or the maximum pressure for eardrum rupture, respectively.

Table 7 - Tabular view of the critical distances

Таблица 7 - Табличное отображение критического расстояния Табела 7 - Табеларни приказ критичног растојања

\begin{tabular}{|c|c|c|c|c|c|c|}
\hline Type of explosive & Unit & \multicolumn{5}{|c|}{ AMONEX 1 } \\
\hline Experiment number N & & 1 & 2 & 3 & 4 & 5 \\
\hline $\begin{array}{c}\text { Critical distance R, Sadovsky } \\
\text { method (Andreev et al, 2004) } \\
(6,9 \mathrm{kPa})\end{array}$ & $\mathrm{m}$ & 10.53 & 10.90 & 11.48 & 11.98 & 12.59 \\
\hline $\begin{array}{c}\text { Critical distance R, Sadovsky } \\
\text { method (Bajić et al, 2009) } \\
(6,9 \mathrm{kPa})\end{array}$ & $\mathrm{m}$ & 12.98 & 13.45 & 14.16 & 14.78 & 15.52 \\
\hline $\begin{array}{c}\text { Critical distance R, Kingery- } \\
\text { Bulmash method } \\
(6,9 \mathrm{kPa})\end{array}$ & $\mathrm{m}$ & 9.93 & 10.30 & 10.82 & 11.32 & 11.88 \\
\hline $\begin{array}{c}\text { Critical distance R, Sadovsky } \\
\text { method (Andreev et al, 2004) } \\
(35 \mathrm{kPa})\end{array}$ & $\mathrm{m}$ & 3.36 & 3.48 & 3.66 & 3.82 & 4.01 \\
\hline $\begin{array}{c}\text { Critical distance R, Sadovsky } \\
\text { method (Bajić et al, 2009) } \\
(35 \mathrm{kPa})\end{array}$ & $\mathrm{m}$ & 4.20 & 4.35 & 4.58 & 4.78 & 5.02 \\
\hline $\begin{array}{c}\text { Critical distance R, Kingery- } \\
\text { Bulmash method } \\
(35 \mathrm{kPa})\end{array}$ & $\mathrm{m}$ & 3.12 & 3.23 & 3.39 & 3.55 & 3.72 \\
\hline
\end{tabular}




\section{Conclusion}

The critical distance of the explosion obtained by the Sadovsky method, under the condition of the maximum pressure for temporary hearing loss, is $12.59 \mathrm{~m}$ and $15.52 \mathrm{~m}$, respectively. The critical distance of the explosion obtained by the Sadovsky method, under the condition of the maximum pressure for eardrum burst is 4.01 and $5.02 \mathrm{~m}$, respectively.

The critical explosion distance obtained by the Kingery-Bulmash method, under the condition of the maximum pressure for temporary hearing loss is $11.88 \mathrm{~m}$. The critical explosion distance obtained by the Kingery-Bulmash method, under the condition of the maximum pressure for the eardrum to burst is $3.72 \mathrm{~m}$.

The calculated value of the critical explosion distance by the Kingery-Bulmash method, under the condition of the maximum pressure for temporary hearing loss, is $5.62 \%$ lower than the distance obtained by the Sadovsky method according to the coefficients from (Andreev et al, 2004 ) and $23.47 \%$ according to the coefficients from (Bajić et al, 2009).

The value of the critical explosion distance calculated by the Kingery-Bulmash method, under the condition of the maximum burst pressure, is $7.83 \%$ lower than the distance obtained by the Sadovsky method according to the coefficients from (Andreev et al, 2004) and $26.31 \%$ according to the coefficients from (Bajić et al, 2009).

The presented results refer to the maximum equivalent mass of explosives (experiment number 5) shown in Table 2.

Sadovsky's equation was originally developed for very large quantities of explosives, so its applicability in the considered cases is questionable.

The Kingerey-Bulmash method is used in international regulations and is more applicable in these cases as well.

\section{References}

Andreev, S.G., Babkin, A.V. \& Baum, F.A. 2004. Fizika vzryva (Ed: Orlenko, L.P.). Moscow: Fizmatlit (in Russian). ISBN: 5-9221-0218-4. (In the original: Андреев, С.Г., Бабкин, А.В., Баум, Ф.А. 2004. Физика взрыва (ред: Орленко, Л.П.). Москва: Физматлит).

Bajić, Z., Bogdanov, J. \& Jeremić, R. 2009. Blast Effects Evaluation Using TNT Equivalent. Scientific Technical Review, 59(3-4), pp.50-53 [online]. Available at: http://www.vti.mod.gov.rs/ntp/rad2009/34-09/7/7.pdf [Accessed: 18 February 2020]. 
Bataev, I., Tanaka, A.S., Zhou, Q., Lazurenko, D.V., Jorge Junior, A.M., Bataev, A.A., Hokamoto, K., Mori, A. \& Chen, P. 2019. Towards better understanding of explosive welding by combination of numerical simulation and experimental study. Materials \& Design, 169(art.number:107649). Available at: https://doi.org/10.1016/j.matdes.2019.107649.

Beveridge, A. 2011. Forensic Investigation of Explosions. Boca Raton, Florida: CRC Press. ISBN: 9781420087260.

-BlackBox Biometrics. 2018. The Blast gauge System. Pressure thresholds: what your medic needs to know [online]. Available at: http://quwdb2fvzocb4glqwropj20o-wpengine.netdna-ssl.com/wpcontent/uploads/2018/10/White-Paper-Pressure-Thresholds-v4.pdf [Accessed: 18 February 2020].

Blazynski, T.Z. 1983. Explosive Welding Forming and Compaction. Dordrecht, NL: Springer. Online ISBN: 978-94-011-9751-9. Available at: https://doi.org/10.1007/978-94-011-9751-9.

Brode, H.L. 1955. Numerical solutions of spherical blast waves. Journal of Applied Physics, 26(6), pp.766-775. Available at: https://doi.org/10.1063/1.1722085.

Gan, R.Z., Nakmali, D.U., Ji, X.D., Leckness, K. \& Yokell, Z. 2016. Mechanical damage of tympanic membrane in relation to impulse pressure waveform - A study in chinchillas. Hearing Research, 340, pp.25-34. Available at: https://doi.org/10.1016/j.heares.2016.01.004.

Ghomi, M.T. 2009. Impact wave process modeling and optimization in high energy rate explosive welding. Västerås, Sweden: Mälardalen University Press. Online ISBN: 978-91-86135-35-5 [online]. Available at: https://www.divaportal.org/smash/get/diva2:232277/FULLTEXT03.pdf [Accessed: 21 January 2020].

Jeremić, R. 2002. Eksplozivni procesi. Belgrade: General Staff of the Yugoslav Army, Directorate for Education (in Serbian).

Kingery, C.N. \& Bulmash, G. 1984. Technical report ARBRL-TR-02555: Air blast parameters from TNT spherical air burst and hemispherical burst, AD-B082 713. U.S. Army Ballistic Research Laboratory, Aberdeen Proving Ground, MD.

Kinney, G.F. \& Graham, K.J. 1985. Explosive Shocks in Air. Berlin, Heidelberg: Springer-Verlag. Available at: https://doi.org/10.1007/978-3-64286682-1.

-Manufacturing Guide. 2020. Explosion Welding [online]. Available at: https://www.manufacturingguide.com/en/explosion-welding [Accessed: 02 February 2020].

-NATO. 2010. Manual of NATO safety principles for the storage of military ammunition and explosives, AASTP-1, Change 3 [online]. Available at: http://www.rasrinitiative.org/pdfs/AASTP-1-Ed1-Chge-3-Public-Release110810.pdf [Accessed: 18 February 2020].

Panowicz, R., Konarzewski, M. \& Trypolin , M. 2017. Analysis of Criteria for Determining a TNT Equivalent. Strojni ški vestnik - Journal of Mechanical Engineering, 63(11), pp.666-672. Available at: https://doi.org/10.5545/svjme.2016.4230. 
Pejčinović, M. 2000. Analiza postupaka obrade eksplozijom. Graduate thesis. Kragujevac: University of Kragujevac, Faculty of Engineering (in Serbian).

Sadovsky, M.A. 1952. Mehanicheskoe dejstvie vozdushnyh udarnyh voln vzryva po dannym jeksperimental'nyh issledovanij. In: Sadovsky, M.A. \& Beljaev, A.F. (Eds.) Fizika vzryva, Sbornik No. 1, pp.20-110. Moscow: USSR Academy of Sciences Publishing House [online]. Available at: http://elib.biblioatom.ru/text/fizika-vzryva_1_1952/go,20/ (in Russian) [Accessed: 2 February 2020]. (In the original: Садовский, М.A. 1952. Механическое действие воздушных ударных волн взрыва по данным экспериментальных исследований. В: Садовский, М.А. и Беляев, А.Ф. (Ред.) Физика взрыва, Сборник Но. 1, с.20-110. Москва: Издательство Академии наук СССР [онлайн]. Доступно на: http://elib.biblioatom.ru/text/fizika-vzryva_1_1952/go,20/ [Дата посещения: 2 февраля 2020 г]).

Shangyuan, J. 2018. Mechanical properties of human incudostapedial joint and tympanic membrane in normal and blast-damaged ears. Ph.D. thesis. Norman, OK: University of Oklahoma [online]. Available at: https://hdl.handle.net/11244/299908 [Accessed: 02 February 2020].

Solomos, G., Larcher, M., Valsamos, G., Karlos, V. \& Casadei, F. 2020. A survey of computational models for blast induced human injuries for security and defence applications. Luxembourg: Publications Office of the European Union. Online ISBN: 978-92-76-14659-9. Available at: https://doi.org/10.2760/685.

Stamatović, A. 1995. Konstruisanje projektila. Belgrade: Ivexy (in Serbian).

Stewart, C. 2006. Blast Injuries: Preparing for the Inevitable. Emergency Medical Practic, 8(4) [online]. Available at: http://www.storysmith.net/page5/files/Blast\%20Injuries\%200406.pdf [Accessed: 21 January 2020].

-Trayal corporation. 2008. Technological procedure for making industrial powdered explosives. Serbian Patent number WO2008009031A1 [online]. Available at: https://patents.google.com/patent/WO2008009031A1/en [Accessed: 18 February 2020].

-Trayal corporation. 2020. Powder explosives [online]. Available at: https://trayal.rs/en/products/explosives/explosives-and-initiating-

devices/explosives/explosive-cartridges/\#599 [Accessed: 02 February 2020].

- United Nations. 2015. International Ammunition Technical Guideline Formulae for ammunition management. IATG 01.80. Second ed. [online]. Available at: https://s3.amazonaws.com/unoda-web/wpcontent/uploads/2019/05/IATG-01.80-Formulae-for-Ammunition-Management-

V.2.01.pdf [Accessed: 18 February 2020].

Waldau, B., Huang, J.H., Winn, H.R. \& Grant, G.A. 2015. Blast-Induced Neurotrauma, Chapter 337 [online]. Available at: https://clinicalgate.com/blastinduced-neurotrauma/ [Accessed: 18 February 2020]. 
ОПРЕДЕЛЕНИЕ КРИТИЧЕСКОГО РАССТОЯНИЯ ПРИ СВАРКЕ ВЗРЫВОМ

Милош С. Лазаревич ${ }^{a}$, Богдан П. Недич ${ }^{a}$, корреспондент,

Йовица Дж. Богданов ${ }^{\circ}$, Стефран В. Джурич ${ }^{a}$

а Крагуевацкий университет, Факультет инженерных наук,

г. Крагуевац, Республика Сербия

${ }^{б}$ Университет обороны в г. Белград, Военная академия, Департамент военного химического инжиниринга, г. Белград, Республика Сербия

РУБРИКА ГРНТИ: 55.00.00 МАШИНОСТРОЕНИЕ:

55.01.93 Условия труда, социально-бытовые мероприятия (услуги), охрана труда, техника безопасности

ВИД СТАТЬИ: оригинальная научная статья

Резюме:

Введение/цель: При проведении сварочных работ методом взрыва всем сотрудникам необходимо придерживаться техники безопасности, соблюдая все правила преосторожности, в первую очередь не нарушать критическое расстояние между рабочими и местом взрыва в момент взрыва. Небрежность или невнимательность могут привести к временной потере слуха, разрыву барабанной перепонки и, в некоторых случаях, даже к смерти сотрудников. Целью данной работы является определение критического расстояния на основании массы заряда взрывчатого вещества, необходимой для сварки взрывом, при условии, что предельное давление в случае временной потери слуха составляет 6,9 кПа, а в случае разрыва барабанной перепонки составляет 35 кПа. В данной статье не приведены иные методы, кроме взрыва, вызванного ударной волной.

Методы: Эквивалентные массы взрывчатых веществ рассчитываются в зависимости от типа взрыва. На основании эквивалентной массы взрывчатых веществ и предельного давления, применяя уравнение Садовского и Кингери и Булмаша рассчитывается минимально допустимое расстояние.

Результаты: В соответствующих таблицах приведены результаты расчета критического расстояния рабочих от места взрыва, который может вызвать временную потерю слуха или разрыв барабанной перепонки. Расчетное значение критического расстояния взрыва, вычисленное по методу Кингери и Булмаша при условии максимального давления, вызывающем временную потерю слуха составило на 7,83\% меньше, чем расстояние, полученное методом Садовского, в то время как расчетное значение критического расстояния от 
взрыва, вычисленное по методу Кингери и Булмаша при условии максимального давления разрыва барабанной перепонки составило на 7,83\% меньше расстояния, полученного методом Садовского.

Вывод: Результаты расчета показали, что критическое расстояние от взрыва можно успешно рассчитать, а также, что полученные значения несущественно различаются вне зависимости от применяемого метода расчета.

Ключевые слова: сварка взрывом, критическое расстояние, ударная волна, повреждение барабанной перепонки, матрица риска.

\section{ОДРЕЪИВАЊЕ КРИТИЧНОГ РАСТОЈАЊА У ПОСТУПКУ} ЕКСПЛОЗИВНОГ ЗАВАРИВАЊА

Милош С. Лазаревић ${ }^{a}$, Богдан П. Недић ${ }^{a}$, аутор за преписку, Јовица Ђ. Богданов ${ }^{\sigma}$, Стефран В. Ђурић $^{a}$

а Универзитет у Крагујевцу, Факултет инжењерских наука, Крагујевац, Република Србија

${ }^{б}$ Универзитет одбране у Београду, Војна академија, Катедра војнохемијског инжењерства, Београд, Република Србија

ОБЛАСТ: машинство

ВРСТА ЧЛАНКА: оригинални научни рад

\section{Сажетак:}

Увод/циљ: При извођењу поступка експлозивног заваривања потребно је водити рачуна о минималном растојању између запослених или извођача и места експлозије у тренутку експлозије. Немарност или нехат може проузроковати привремени губитак слуха, пуцање бубне опне, а у неким случајевима чак и смрт. Циљ овог рада је да се на основу масе експлозивног пуњења, која је потребна за експлозивно заваривање, одреди критично растојање под условом да је у случају привременог губитка слуха гранични притисак $6,9 \mathrm{kPa}$, а у у случају пуцања бубне опне $35 \mathrm{kPa}$ У раду се не узимају $у$ обзир други ефректи експлозије осим они проузроковани ударним таласом.

Meтоде: У зависности од типа експлозије, прорачуната је еквивалентна маса експлозива. На основу ње и граничног притиска израчуната су минимална растојања применом једначине Садовског и Kingerey-Bulmash-a.

Резултати: У одговарајућим табелама приказани су резултати прорачуна критичног растојања радника од места експлозије

\section{3}


када може доћи до привременог губитка слуха, односно пуцања бубне опне. Критична удаљеност од експлозије израчуната методом Kingerey-Bulmash, под условом максималног притиска привременог губитка слуха, за 5,62\% је мања од растојања добијеног методом Садовског, док је критична удаљеност од експлозије израчуната методом Kingerey-Bulmash-a, под условом максималног притиска пуцања бубне опне, за 7,83\% мања од растојања добијеног методом Садовског.

Закључак: Резултати прорачуна су показали да се критична удаљеност од експлозије може успешно прорачунати и да добијене вредности имају мале разлике у зависности од примењене методе за прорачун.

Кључне речи: заваривање експлозијом, критично растојање, ударни талас, оштећење бубне опне, матрица ризика.

Paper received on / Дата получения работы / Датум пријема чланка: 21.05.2020. Manuscript corrections submitted on / Дата получения исправленной версии работы / Датум достављања исправки рукописа: 01.08.2020.

Paper accepted for publishing on / Дата окончательного согласования работы / Датум коначног прихватања чланка за објављивање: 03.08.2020.

(C) 2020 The Authors. Published by Vojnotehnički glasnik / Military Technical Courier (www.vtg.mod.gov.rs, втг.мо.упр.срб). This article is an open access article distributed under the terms and conditions of the Creative Commons Attribution license (http://creativecommons.org/licenses/by/3.0/rs/).

(c) 2020 Авторы. Опубликовано в «Военно-технический вестник / Vojnotehnički glasnik / Military Technical Courier» (www.vtg.mod.gov.rs, втг.мо.упр.срб). Данная статья в открытом доступе и распространяется в соответствии с лицензией «Creative Commons» (http://creativecommons.org/licenses/by/3.0/rs/).

(C) 2020 Аутори. Објавио Војнотехнички гласник / Vojnotehnički glasnik / Military Technical Courier (www.vtg.mod.gov.rs, втг.мо.упр.срб). Ово је чланак отвореног приступа и дистрибуира се у складу са Creative Commons лиценцом (http://creativecommons.org/licenses/by/3.0/rs/). 